\title{
Morphologic Relationship Between the Coronary Arteries During Fetal Development
}

\author{
Relación Morfológica Entre las Arterias Coronarias Durante el Desarrollo Fetal
}

\author{
S. Singh; N. Ajayi; L. Lazarus \& K. S. Satyapal
}

SINGH, S.; AJAYI, N.; LAZARUS, L. \& SATYAPAL, K. S. Morphologic relationship between the coronary arteries during fetal development. Int. J. Morphol., 35(4):1197-1202, 2017.

SUMMARY: A detailed understanding of the coronary arteries is of paramount importance in the management of coronary arterial diseases. The arterial supply to the heart originates from right (RCA) and left (LCA) coronary arteries which form an oblique inverted crown within the atrioventricular groove. This study aimed to document the embryologic relationship between the RCA and the LCA including their lengths, diameters, branching patterns and arterial dominance in fetuses. Forty-one human fetal heart specimens with an age range of 13.13 to 26.95 weeks were dissected at the Department of Clinical Anatomy, University of Kwazulu-Natal, Durban, South Africa. The RCA arose from the right aortic sinus and was dominant in all the specimens. The LCA was classified into types according to their branching pattern. The bifurcation, trifurcation and quadrifurcation of the LCA occurred in $68.3 \%, 29.3 \%$ and $2.4 \%$ of hearts, respectively. The mean lengths of the RCA and LCA were $0.98 \pm 0.54 \mathrm{~mm}$ and $1.83 \pm 0.77 \mathrm{~mm}$, respectively. The mean external diameters of the RCA and LCA were $0.38 \pm 0.12 \mathrm{~mm}$ and $0.49 \pm 0.17 \mathrm{~mm}$, respectively. There was a significant correlation between the RCA and LCA length and the fetal age which is indicative of significant changes in the coronary vasculature with fetal growth.

KEY WORDS: Right coronary artery; Left coronary artery; Branching patterns; Bifurcation; Trifurcation; Quadrifurcation.

\section{INTRODUCTION}

Early embryonic circulation is symmetrical and is modified throughout development (Standring et al., 2015). The formation of the coronary arteries begins in the third week and involves a series of carefully regulated events including vasculogenesis, angiogenesis, arteriogenesis and remodelling (Tomanek et al., 2005; Silva-Junior et al., 2009). The embryonic coronary arteries have been described by two definitions of physiological development (Silva-Junior et al.). It was initially assumed that the coronary arteries were formed by outgrowths from the aorta, however, this has never been documented (Ando et al., 2004). Bogers et al. (1989) reported that coronary arteries develop through ingrowth of the vessels by demonstrating that the coronary arteries could be identified in the walls of the aortic sinuses before the formation of the coronary orifices. It is now largely accepted that the proximal coronary arteries develop from a complex capillary network derived from epicardial mesenchyme and not as sprouting and branching outgrowths of the aorta (Santhoshkumar et al., 2014).
The RCA and LCA provide the arterial supply to the heart by forming an oblique inverted crown within the atrioventricular groove (Moore et al., 2010; Standring et al.). The major branches of the coronary arteries are typically subepicardial, however, those in the coronary sulcus are deeply sited and frequently embedded in the myocardium (Snell, 2012; Standring et al.). Anastomoses of the right and left coronary arteries occur frequently in the fetus but decreases by the end of the first year (Standring et al.). A dominant artery refers to the coronary artery providing the posterior interventricular branch (PIB) which supplies the posterior ventricular septum and frequently part of the posterolateral wall of the left ventricle (Pelter et al., 2011). The RCA is usually dominant with varying incidence ranging from $55 \%$ to $89.6 \%$ (Angelini et al., 2002; Kim et al., 2006; Loukas et al., 2006; Altin et al., 2015; Standring et al.).

Right Coronary Artery. Arising from the right aortic sinus, the RCA runs in the coronary sulcus between the right atrium

Department of Clinical Anatomy, School of Laboratory Medicine and Medical Sciences, College of Health Sciences, Westville Campus, University of Kwazulu-Natal, Private Bag X54001, Durban 4000, South Africa. 
and right ventricle (Drake et al., 2014). The first branch of the RCA is usually the right conal artery, however, this artery arises independently in one third of hearts (Standring et al.). Descending in the coronary sulcus, the RCA gives off anterior atrial and ventricular branches that diverge widely (Sinnatamby, 2011). A branch running toward the apex of the heart, termed the right marginal artery is greater in calibre than other anterior ventricular arteries (Snell). At the posterior aspect of the heart, the RCA passes through the junction of the interatrial and interventricular septa between the four heart chambers (the crux) and gives rise to up to three small interventricular branches including the PIB (Standring et al.). The PIB descends toward the apex in the posterior interventricular groove and supplies the posterior interventricular septum (Moore et al.; Standring et al.). The terminal branch of the RCA, termed the posterior left ventricular branch, then continues briefly in the coronary sulcus (Moore et al.). The RCA supplies the right chambers, some parts of the left chambers and the atrioventricular septum (Drake et al.).

Left Coronary Artery. The LCA is larger in calibre and supplies a greater volume of the myocardium including the left chambers and most of the interventricular septum (Snell). Originating from the left aortic sinus, the LCA passes between the left auricle and pulmonary trunk to traverse the coronary sulcus (Drake et al.). The LCA divides into two or three branches at the atrioventricular groove viz. the anterior interventricular branch (AIB) and the circumflex artery (CX) (Moore et al.; Standring et al.). The AIB continues to the apex of the heart and commonly anastomoses with the PIB of the RCA on the posterior aspect of the heart (Sinnatamby). The AIB gives off right and left anterior ventricular, anterior septal and corresponding posterior branches (Standring et al.). The largest anterior ventricular branch is referred to as the diagonal artery and may be doubled (Drake et al.). The CX artery follows the coronary sulcus and terminates on the posterior aspect of the heart before reaching the crux, however, it sometimes continues as the PIB in cases of left dominance (Moore et al.; Standring et al.). The CX supplies the left ventricle by its left marginal branch (Moore et al.).

In addition to the AIB and CX arteries, the LCA can give rise to one or two additional terminal branches referred to as median or intermedian arteries (Dattatray et al., 2012; Chougule et al., 2014). The median artery can originate from the vertex of the angle between the AIB and $\mathrm{CX}$ arteries including the proximal part of the AIB and CX arteries (Ajayi et al., 2013; Chougule et al.). From the literature reviewed, there is paucity of reports on the anatomic relationship of the development of the RCA and the LCA in fetuses. Therefore, this study aimed to document the embryologic relationship between the proximal RCA and LCA in fetal hearts including the arterial dominance and branching patterns.

\section{MATERIAL AND METHOD}

A sample of 50 human fetal heart specimens were dissected at the Department of Clinical Anatomy, University of Kwazulu-Natal, Westville campus, Durban, South Africa in accordance with the National Health Act no 61 of 2003. In 9 fetuses, the hearts presented with congenital malformations and were therefore excluded resulting in a sample size of 41 dissected hearts with an age range of 13.13 to 26.95 weeks.

Gestational age was estimated using the formula $y$ $=7.130+0.503 \mathrm{x}$, where $\mathrm{y}=$ gestational age in weeks and $\mathrm{x}=$ fetal foot length in $\mathrm{mm}$ (Pandey et al., 2015). The length and external diameter of the proximal RCA and LCA was measured with the length of the RCA measured from its origin to its first branch. The branching patterns of the RCA and LCA were documented. The relationship between the development of the RCA and the LCA was examined. The LCA was classified into types according to their branching pattern (Tomar et al., 2013; Chougule et al.). The LCA Type A occurred when the artery bifurcated into AIB and CX arteries, Type B occurred when the LCA trifurcated into AIB, median and CX arteries and Type $\mathrm{C}$ was categorised as quadrifurcating into AIB, two median arteries and a CX artery.

\section{RESULTS}

In all the specimens, the RCA arose from the right aortic sinus and traversed the coronary sulcus before giving rise to the PIB on the posterior surface of the heart. The RCA gave rise to the PIB in all cases, and therefore right dominance occurred in $100 \%\left({ }^{41} / 41\right)$ of cases. The LCA was divided into types according to the branching pattern. LCA Type A (bifurcation) (Fig. 1) occurred in $68.3 \%\left({ }^{28} /{ }_{41}\right.$ ) of specimens, Type B (trifurcation) (Fig. 2) occurred in $29.3 \%$ $\left({ }^{12} / 41\right.$ ) of cases and Type C (quadrifurcation) (Fig. 3) occurred in $2.4 \%\left(1 /{ }_{41}\right)$ of cases.

The mean length of the proximal RCA was found to be $0.98 \pm 0.54 \mathrm{~mm}$ (range $0.3-2.2 \mathrm{~mm}$ ) and the mean external diameter of the RCA was found to be $0.38 \pm 0.12$ $\mathrm{mm}$ (range $0.1-0.6 \mathrm{~mm}$ ). The mean lengths of the LCA 


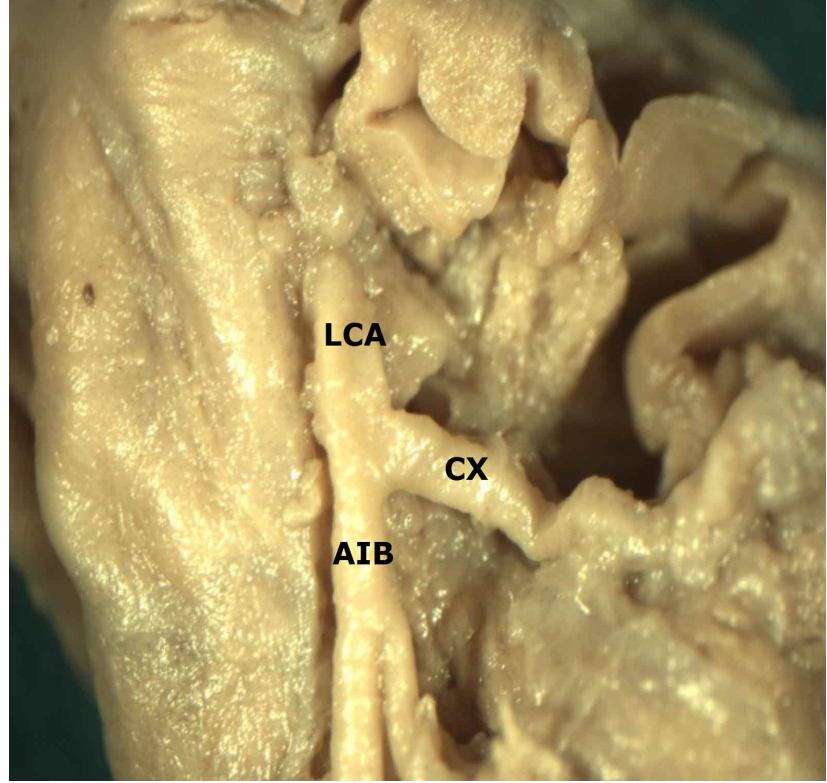

Fig. 1. Bifurcation of the LCA (Type A). LCA - left coronary artery, AIB - anterior interventricular branch, CX - circumflex branch, MA - median artery.

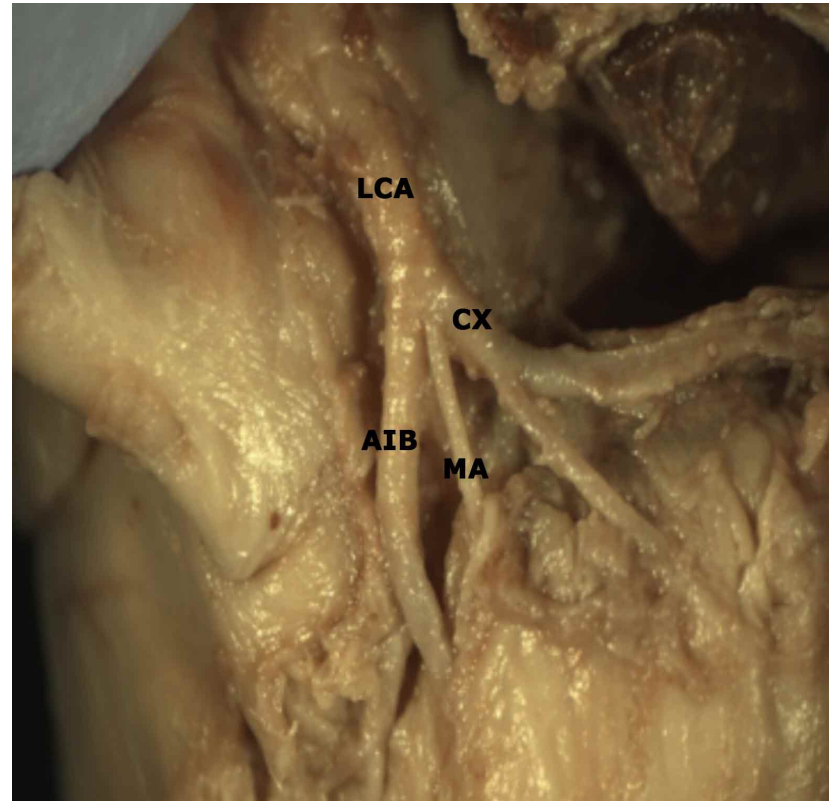

Fig. 2. Trifurcation of the LCA (Type B). LCA - left coronary artery, AIB - anterior interventricular branch, CX - circumflex branch, MA - median artery.

Table I. Means of lengths and diameters.

\begin{tabular}{lccc}
\hline & Mean & Std Dev $(\mathbf{m m})$ & Range $(\mathbf{m m})$ \\
\hline RCA Length & 0.98 & 0.54 & $0.3-2.2$ \\
RCA Diameter & 0.38 & 0.12 & $0.1-0.6$ \\
LCA Length & 1.83 & 0.77 & $0.3-3.5$ \\
LCA Diameter & 0.49 & 0.17 & $0.2-1.0$ \\
\hline
\end{tabular}

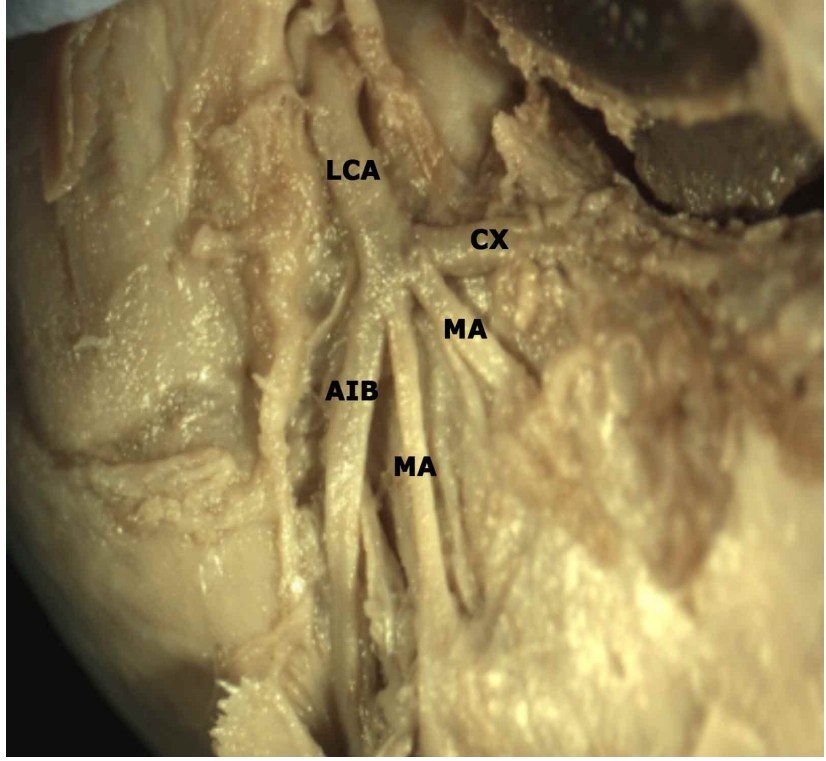

Fig. 3. Quadrifurcation of the LCA (Type C). LCA - left coronary artery, AIB - anterior interventricular branch, CX - circumflex branch, MA - median artery.

and its external diameter were $1.83 \pm 0.77 \mathrm{~mm}$ (range 0.3 $-3.5 \mathrm{~mm}$ ) and $0.49 \pm 0.17 \mathrm{~mm}$ (range $0.2-1.0 \mathrm{~mm}$ ), respectively (Table I). The Pearson product-moment correlation test found a significant positive association between the gestational age (in weeks) of the fetuses and the length of the LCA producing a $r$ value of 0.57 and a $p$ value of 0.0001 . A significant positive correlation was also found between the age (in weeks) and the length of the RCA with a $r$ value of 0.39 and a $p$ value of 0.0127 . A positive correlation was found between the age (in weeks) and the LCA diameter producing a $r$ value of 0.39 and a $p$ value of 0.0109. There was also a significant relationship between the gestational age and the diameter of the RCA resulting in a $r$ value of 0.64 and a $p$ value of 0.001 . In addition, there was a positive association between the lengths of the RCA and LCA with a r value of 0.42 and a $p$ value of 0.0056 . However, there was no correlation between the length and branching patterns of the LCA producing a $r$ value of 0.17 and a $p$ value of 0.2958 (Table II).

Table II. Statistical analysis showing results of Pearson productmoment correlations.

\begin{tabular}{lll}
\hline Variables & $\boldsymbol{r}$ value & $\boldsymbol{p}$ value \\
\hline Gestational age and length of LCA & 0.57 & 0.0001 \\
Gestational age and length of RCA & 0.39 & 0.0127 \\
Gestational age and diameter of LCA & 0.39 & 0.0109 \\
Gestational age and diameter of RCA & 0.64 & $<0.001$ \\
Lengths of RCA and LCA & 0.42 & 0.0056 \\
Length and branching patterns of LCA & 0.17 & 0.2958 \\
\hline
\end{tabular}




\section{DISCUSSION}

Various studies regarding coronary vasculature use predominantly adult subjects, hence, little consideration has been given to fetal coronary anatomy (Nowak et al., 2008). By investigating fetal vessel dimensions, the influence of secondary factors such as atherosclerosis and arterial hypertension can be excluded (Nowak et al., 2009).

In this study, the proximal RCA and LCA were present in all specimens and the absence of the LCA and split RCA was not documented. The RCA arose from the right aortic sinus and gave rise to the PIB in all the hearts. Nowak et al. (2008) reported on coronary vascular anatomy in fetuses and recorded right, left and co-dominant circulation as $32.5 \%, 38 \%$ and $29.5 \%$, respectively. This differed from the current study in which all the fetal heart specimens had right dominance. As noted earlier, from the literature reviewed, there is paucity of reports on the anatomic relationship of the development of RCA and LCA in human fetal specimens. Therefore, the results of the present study were compared to adult studies. Type A (bifurcation) occurred in $68.3 \%$ of hearts and was similar to Dattatray et al. (54.7\%), Tomar et al. (76\%), Ogeng'o et al. (2014) $(54.8 \%)$ and Santhoshkumar et al. (70 \%). However, it disagreed with Kalpana (2003) who found $47 \%$ and Beg et al. (2015) who found $45 \%$ (Table III).

LCA Type B (trifurcation), occurred in $29.3 \%$ and was similar to Dattatray et al. (35.9\%), Ajayi et al. (2013) (18.5\%), Tomar et al. (24\%), Ogeng'o et al. (32.2\%) and Santhoshkumar et al. (26\%). This differed from the results of Kulkarni \& Mehta (2012) and Jaishree et al. (2015) who found $11.54 \%$ and $14.5 \%$, respectively (Table III).

Quadrifurcation of the LCA (Type C) was recorded in $2.4 \%$ of the specimens and was similar to the reports of Ajayi et al. (2013) (0.7\%), Santhoshkumar et al. (2\%) and Jaishree et al. (4\%). The incidence of Type $\mathrm{C}$ was however lower than that of Kalpana, Ogeng'o et al. and Beg et al., and who recorded $11 \%, 9.6 \%$ and $10 \%$, respectively (Table III). Study of the distribution of the LCA aids in providing information on the area of the myocardium supplied (Jaishree et al.). In the case of occlusion of the CX or AIB, the additional median arteries constitute a significant source of collateral circulation to the heart (Ogeng'o et al.). This is due to the potential of these additional arteries to supply a significant area of the myocardium (Ogeng'o et al.).

Since the LCA supplies a greater expanse of the heart, trifurcation of the LCA decreases left main impedance by providing a hydrodynamic advantage (Mamatha \& Sridhar, 2014). A large median artery can also provide electrical stability by protecting against ventricular fibrillation during acute occlusion of the AIB (Mamatha \& Sridhar). Conversely, a large median artery may result in the presence of diminutive diagonal or left marginal arteries (Mamatha \& Sridhar). A small median branch is also predisposed to atherosclerosis since it can restrict blood flow of the left main trunk (Mamatha \& Sridhar).

The significant positive correlation between the lengths of the LCA and RCA with the fetal age indicated that there are significant changes in the development of the coronary vasculature with fetal heart development. There was also a significant association between the lengths of the RCA and LCA. However, the length of the LCA showed a higher significant correlation $(\mathrm{r}=0.57, \mathrm{p}=0.0001)$ with age than the length of the proximal RCA $(r=0.39, p=0.0127)$. This may suggest that the LCA grows faster than the RCA during fetal development. Ajayi et al. (2015), reported that $20.5 \%$ of the patients with absent LCA had splitting of the RCA and suggested that in such patients during development of the coronary arteries there is fast ingrowth of the primitive coronary vascular network in both the left and right coronary vascular tree.

Table III. Incidence of LCA types.

\begin{tabular}{|c|c|c|c|c|}
\hline Authors & Sample Size & $\begin{array}{c}\text { Type A (bifurcation) } \\
(\%)\end{array}$ & $\begin{array}{c}\text { Type B (trifurcation) } \\
(\%)\end{array}$ & $\begin{array}{c}\text { Type } \mathrm{C} \\
\text { (quadrifurcation) (\%) }\end{array}$ \\
\hline Kalpana (2003) & 100 & 47 & 40 & 11 \\
\hline Dattatray et al. (2012) & 64 & 54.7 & 35.9 & 7.8 \\
\hline Kulkarni \& Mehta (2012) & 107 & - & 11.54 & - \\
\hline Tomar et al. (2013) & 50 & 76 & 24 & - \\
\hline Ajayi et al. (2013) & 151 & 80.8 & 18.5 & 0.7 \\
\hline Ogengo et al. (2014) & 208 & 54.8 & 32.2 & 9.6 \\
\hline $\begin{array}{l}\text { Santhoshkumar et al. (2014) } \\
\text { Chougule et al. (2014) }\end{array}$ & $\begin{array}{l}50 \\
50\end{array}$ & $\begin{array}{l}70 \\
35\end{array}$ & $\begin{array}{l}26 \\
15\end{array}$ & $\begin{array}{l}2 \\
-\end{array}$ \\
\hline Jaishree et al. (2015) & 76 & 81.5 & 14.5 & 4 \\
\hline Beg et al. (2015) & 40 & 45 & 42.5 & 10 \\
\hline Present Study & 41 & 68.3 & 29.3 & 2.4 \\
\hline
\end{tabular}


The size of the coronary arteries typically determines the treatment options in the management of coronary artery disease as small arteries may cause anastomotic difficulties during bypass grafting and can influence the outcome in procedures such as stenting and balloon angioplasty (Ajayi et al., 2013).

\section{CONCLUSION}

A significant correlation between the gestational age and the lengths of the proximal RCA and LCA was recorded. This is indicative of the significant changes in the coronary vasculature with fetal growth as there is an increase in nutritional and oxygen demand.

SINGH, S.; AJAYI, N.; LAZARUS, L. \& SATYAPAL, K. S. Relación morfológica entre las arterias coronarias durante el desarrollo fetal. Int. J. Morphol., 35(4):1197-1202, 2017.

RESUMEN: Una comprensión detallada de las arterias coronarias es de suma importancia en el manejo de las enfermedades en estas arterias. El suministro arterial al corazón se origina de las arterias coronarias derecha (ACD) e izquierda (ACI) que forman una "corona oblicua invertida" dentro del surco atrioventricular. Este estudio tuvo por objetivo documentar la relación embriológica entre la ACD y la ACI, incluyendo sus longitudes, diámetros, patrones de ramificación y dominio arterial en fetos. Se disecaron 41 corazones de fetos humanos con un rango de edad de 13,13 a 26,95 semanas, en el Departamento de Anatomía Clínica, Universidad de Kwazulu-Natal, Durban, Sudáfrica. La ACD surgió del seno aórtico derecho y fue dominante en todos los especímenes. La ACI se clasificó en distintos tipos según su patrón de ramificación. La bifurcación, trifurcación y cuadrifurcación de la ACI ocurrieron en $68,3 \%, 29,3 \%$ y 2,4 $\%$ de los corazones, respectivamente. Las longitudes medias de la ACD y ACI fueron $0,98 \pm 0,54 \mathrm{~mm}$ y $1,83 \pm 0,77 \mathrm{~mm}$, respectivamente. Los diámetros externos medios de la ACD y ACI fueron $0,38 \pm 0,12 \mathrm{~mm}$ y $0,49 \pm 0,17 \mathrm{~mm}$, respectivamente. Hubo una correlación significativa entre la longitud de la ACD y la ACI y la edad fetal, que es indicativa de cambios significativos en la vasculatura coronaria con crecimiento fetal.

PALABRAS CLAVE: Arteria coronaria derecha; Arteria coronaria izquierda; Patrones ramificados; Bifurcación; Trifurcación; Cuadrifurcación.

\section{REFERENCES}

Ajayi, N. O.; Lazarus, L.; Vanker, E. A. \& Satyapal, K. S. Anatomic parameters of the left coronary artery: An angiographic study in a South African population. Int. J. Morphol., 31(4):1393-8, 2013.
Ajayi, N. O.; Lazarus, L.; Vanker, E. A. \& Satyapal, K. S. Absent left main coronary artery with variation in the origin of its branches in a South African population. Anat. Histol. Embryol., 44(2):81-5, 2015.

Altin, C.; Kanyilmaz, S.; Koc, S.; Gursoy, Y. C.; Bal, U.; Aydinalp, A.; Yildirir, A. \& Muderrisoglu, H. Coronary anatomy, anatomic variations and anomalies: a retrospective coronary angiography study. Singapore Med. J., 56(6):339-45, 2015.

Ando, K.; Nakajima, Y.; Yamagishi, T.; Yamamoto, S. \& Nakamura, H. Development of proximal coronary arteries in quail embryonic heart: multiple capillaries penetrating the aortic sinus fuse to form main coronary trunk. Circ. Res., 94(3):346-52, 2004.

Angelini, P.; Velasco, J. A. \& Flamm, S. Coronary anomalies: incidence, pathophysiology, and clinical relevance. Circulation, 105(20):2449-54, 2002.

Beg, M. R. U.; Singh, A.; Goel, S.; Goel, A. K.; Goel, V.; Goyal, P.; Surana, A.; Singh, N. K. \& Dhanda, M. S. Anatomical variations of coronary artery and frequency of median artery: A cadaveric study from Northern India. Int. Arch. Integr. Med., 2(5):88-94, 2015.

Bogers, A. J.; Gittenberger-de Groot, A. C.; Poelmann, R. E.; Péault, B. M. $\&$ Huysmans, H. A. Development of the origin of the coronary arteries, a matter of ingrowth or outgrowth? Anat. Embryol. (Berl.), 180(5):43741,1989

Chougule, P.; Silotry, N. \& Chavan, L. Variation in branching pattern of coronary arteries. Int. J. Sci. Res., 3(8):270-3, 2014.

Dattatray, D. D.; Takkallapalli, A.; Purushottam, G. A.; Swapnali, D. D. \& Medha, V. A. Clinically relevant morphometric analysis of left coronary artery. Int. J. Biol. Med. Res., 3(1):1327-30, 2012.

Drake, R. L.; Vogl, A. W. \& Mitchell, A. W. M. Gray's Anatomy for Students. $3^{\text {rd }}$ ed. Philadelphia, Churchill Livingstone/Elsevier, 2014. pp.198-201.

Jaishree, H.; Kshirsagar, S. V. \& Ashwini, H. Study of origin, course and branching pattern of left coronary artery in Hyderabad Karnataka Region. Natl. J. Integr. Res. Med., 6(2):1-5, 2015.

Kalpana, R. A study on principal branches of coronary arteries in humans. J. Anat. Soc. India, 52(2):137-40, 2003.

Kim, S. Y.; Seo, J. B.; Do, K. H.; Heo, J. N.; Lee, J. S.; Song, J. W.; Choe, Y. H.; Kim, T. H.; Yong, H. S.; Choi, S. I.; Song, K. S. \& Lim, T. H. Coronary artery anomalies: classification and ECG-gated multi-detector row CT findings with angiographic correlation. Radiographics, 26(2):317-33, 2006.

Kulkarni, J. P. \& Mehta, L. Main left coronary artery system - Angiographic anatomy. J. Dent. Med. Sci., 3(2):5-7, 2012.

Loukas, M.; Curry, B.; Bowers, M.; Louis, R. G. Jr.; Bartczak, A.; Kiedrowski, M.; Kamionek, M.; Fudalej, M. \& Wagner, T. The relationship of myocardial bridges to coronary artery dominance in the adult human heart. J. Anat., 209(1):43-50, 2006.

Mamatha, Y. \& Sridhar, C. Anomalous branching pattern of coronary vessels. CIBTech J. Surg., 3(2):17-20, 2014.

Moore, K. L.; Dalley, A. F. \& Agur, A. M. R. Clinically Oriented Anatomy. $6^{\text {th }}$ ed. Philadelphia, Wolters Kluwer Health/Lippincott Williams \& Wilkins, 2010. pp.144-7.

Nowak, D.; Gielecki, J.; Rzeszowska, M. \& Kiestrzyn-Wójcik, A. Types of coronary vasculature in the human fetus: an autopsy study. Cells Tissues Organs, 188(4):393-9, 2008.

Nowak, D.; Gielecki, J.; Zurada, A. \& Góralczyk, K. No relationship between the length of the left coronary artery main stem and the type of coronary vasculature in human fetuses from a morphological perspective. Med. Sci. Monit., 15(1):CR20-5, 2009.

Ogeng'o, J. A.; Misiani, M. K.; Olabu, B. O.; Waisiko, B. M. \& Murunga, A. Variant termination of the left coronary artery: pentafurcation is not uncommon. Eur. J. Anat., 18(2):98-101, 2014.

Pandey, V. D.; Singh, V.; Nigam, G. L.; Usmani, Y. \& Yadav, Y. Fetal foot length for assessment of gestational age: A comprehensive study in North India. Sch. J. Appl. Med. Sci., 3(1C):139-44, 2015.

Pelter, M. M.; Al-Zaiti, S. S. \& Carey, M. G. Coronary artery dominance. Am. J. Crit. Care, 20(5):401-2, 2011.

Santhoshkumar, N. \& Balaji, M. A. The study of origin, course, branching 
SINGH, S.; AJAYI, N.; LAZARUS, L. \& SATYAPAL, K. S. Morphologic relationship between the coronary arteries during fetal development. Int. J. Morphol., 35(4):1197-1202, 2017.

pattern, distribution, and clinical correlation of left coronary artery. Int. J. Bioassays, 3(8):3244-9, 2014.

Silva-Junior, G. O.; Miranda, S. W. S. \& Mandarim-de-Lacerda, C. A. Origin and development of the coronary arteries. Int. J. Morphol., 27(3):891$8,2009$.

Sinnatamby, C. S. Last's Anatomy. Regional and Applied. $12^{\text {th }}$ ed. Edinburgh, Churchill Livingstone/Elsevier, 2011. pp.321-2.

Snell, R. S. Clinical Anatomy by Regions. $9^{\text {th }}$ ed. Philadelphia, Lippincott Williams \& Wilkins, 2012. pp.86-8.

Standring, S. (Ed.). Gray's Anatomy. The Anatomical Basis of Clinical Practice. $41^{\text {st }}$ ed. Edinburgh, Churchill Livingstone Elsevier, 2015.

Tomanek, R. J. Formation of the coronary vasculature during development. Angiogenesis, 8(3):273-84, 2005.

Tomar, S.; Aga, P.; Sharma, P. K.; Manik, P. \& Srivastava, A. K. Normal and variant anatomy of left coronary artery: 64-slice multi detector computed tomography (MDCT) coronary angiographic depiction in North Indian population. Int. J. Sci. Res. Publ., 3(8), 2013.

\author{
Corresponding author: \\ K. S. Satyapal \\ School of Laboratory Medicine and Medical Sciences \\ College of Health Sciences \\ Westville Campus \\ University of Kwazulu-Natal \\ Private Bag X54001 \\ Durban \\ 4000 \\ SOUTH AFRICA
}

E-mail: satyapalk@ukzn.ac.za

Received: 05-01-2017

Accepted: 24-04-2017 